\title{
THE EXPERIENCE OF DISTINGUISHING CONSTRUCTIVELY CHRONOLOGICAL TYPES OF SWORDS OF THE FIRST HALF OF I MILLENNIUM AD IN PRIKAMYE
}

(C) 2019

\author{
Malykh Oleg Olegovych, researcher of Kama Archeologist-Ethnographic Expedition \\ Shmuratko Dmitry Vladimirovich, candidate of historical sciences, head of History Department \\ Perm State Humanitarian Pedagogical University (Perm, Russian Federation)
}

\begin{abstract}
Current trends include the use of mathematical methods for Humanities studies. One of the methods that have proven to be effective in interpreting mass material obtained during archaeological excavations is a discriminant analysis method. Discriminant analysis is a section of mathematical statistics that assumes the presence of an object that was accidentally extracted from one of them. The proposed work is an application of this method for the study of swords used in Prikamye in the first half of I millennium. Based on discriminant analysis data for each subperiod of the first half of the I millennium an attempt will be made to isolate reference finds, which parameters and design features are most characteristic for a certain time interval. On the basis of mathematical calculations rather than a subjective opinion, the author concludes that there were four types of swords used on the territory of the Prikamye. The proposed paper discusses a possibility of dating accidentally found weapons, based on a comparison of the characteristics of their parameters and design with the data of swords originating from closed burial complexes.

Keywords: discriminant analysis; sword; Prikamye; constructive and chronological types; statistical analysis; archaeological research; Great Migration; reference groups of finds; chronological groups; longblade weapons; burial grounds; archaeological sites; Chegandinskaya culture; Mazuninskaya culture; Azelinskaya culture.
\end{abstract}

УДК 94(3)

DOI 10.24411/2309-4370-2019-11202

Статья поступила в редакцию 21.11.2018

\section{ПОВСЕДНЕВНАЯ ЖИЗНЬ ФРАНКОВ ПО ПИСЬМЕННЫМ ИСТОЧНИКАМ ВО ВРЕМЕНА ГРИГОРИЯ ТУРСКОГО: БОЛЕЗНИ, МЕДИЦИНА, ГИГИЕНА И ЕДА}

(C) 2019

Казаков Игорь Валентинович, кандидат исторических наук, доцент кафедры всеобщей истории, права и методики обучения

Самарский государственный соџиально-педагогический университет (г. Самара, Российская Федераџия)

Аннотащия. Данная статья представляет собой попытку сбора и систематизации информации о материальных условиях жизни во Франкском государстве Меровингов в VI столетии. Выбор темы обусловлен необходимостью составления цельной картины быта человека начала раннего средневековья, которая до настоящего времени остается мало исследованной, в отличие от каролингского периода. В качестве источников использованы сочинения Григория Турского, Венанция Фортуната, Сидония Аполлинария, «Хроники» Фредегара, «Книга истории франков» и другие. В статье собраны данные о болезнях и эпидемиях, распространенных в названный период, способах их лечения и состоянии медицины в целом, о гигиене во франкском обществе, а также о рационе и составе продуктов. Собранный материал позволяет утверждать, что: а) источники раннего меровингского периода отличаются чрезвычайной скудостью данных в сфере бытописания; б) франкское общество было весьма уязвимо перед самыми разнообразными болезнями, и приоритет веры перед медициной не позволял им противостоять; в) представления об отсутствии элементарной гигиены в раннем средневековье сильно преувеличены; г) набор потребляемых продуктов отличался простотой и одновременно разнообразием при зачаточных умениях в кулинарии.

Ключевые слова: Меровинги; Григорий Турский; Фредегар; Венанций Фортунат; «Книга истории франков»; повседневная жизнь; Франкское государство; раннее средневековье; болезни; эпидемии; средневековая медицина; гигиена в средневековье; питание в средние века; Салическая правда; материальные условия; VI век.

Несмотря на кажущуюся исследованность темы и обилие письменных источников, попытка реконструирования повседневной жизни королевства франков в VI столетии сопряжена с заметными трудностями. Так называемая «линейная» история отнюдь не является изобретением ученых нового и новейшего времени: любого из историков периода раннего средневековья несравнимо больше, чем бытописание, интересуют свершения великих мира сего, описываемые по хронологическому принципу. В центре повествования всегда находятся войны, восстания и мятежи, церковные дела, матримониальная политика и прочее, но, что самое интересное, - происходящие в сферическом вакууме. Мы в состоянии порой с точностью до недели-месяца рассказать о том, что делал король Хильперик (здесь можно вставить любое имя), куда он отправился, с какими епископами, графами и королями вел переговоры, в итоге получая пьесу, включающую скупое обозначение места действия, указания на статусы действующих лиц, их родственные связи и титулы, диалоги и монологи. «Торжественный зал в замке. Фанфары. Входят король, королева, Гамлет...» [1, с. 13].

При всем этом нарисовать сам замок, картину действия не удается практически никогда. За пределами внимания средневековых историков остаются вещи, которые кажутся им естественными, малоинтересными и потому не требующими особого упоминания: одежда, устройство жилищ, еда, облик городов и деревень, прически и обувь, в конце концов. 
Еще более ситуацию усугубляет бедность изобразительного материала и нищенство архитектурного, оставшиеся современным исследователям от «темных веков». В результате историческое событие предстает перед читателем в чрезвычайно схематичном виде обезличенных кукол-манекенов, выезжающих на сцену, лишенную какого бы то ни было реквизита, для произнесения нескольких фраз.

Желая как-то расцветить описываемые события, в абсолютном большинстве случаев авторы ограничиваются самыми общими понятиями и определениями: «еда», «трапеза», «пища», «имущество», «утварь», «всякое добро», «жилище», «дом», «плоды», «ценные вещи» и т.П., никак их не конкретизируя. Вот типичные примеры из «Книги истории франков»: «Окончив беседу, оба короля сели за трапезу. И среди богатого застолья светлейший государь Гунтрамн так обратился к сотрапезникам...» [2, кн. III, гл. 68]; на столе стояли «по-королевски всевозможные яства» [2, кн. III, гл. 94]; король Гундовальд был облачен в «пышное одеяние» [2, кн. III, гл. 70] и так далее и тому подобное. Первостепенным объектом внимания для анонимного хрониста служит фиксация фактов свершившихся событий, но отнюдь не антураж.

Еще более бедна в этом плане поэзия Венанция Фортуната. Близость епископа Пуатье к королевскому семейству и его знакомства с многими историческими личностями, казалось бы, обещают богатейшую информацию, касающуюся частной жизни власть предержащих. Однако, кроме редких, как острова архипелага, упоминаний о неких «торжественных дворцах» [3, с. 100], «царских чертогах» [4, c. 151] и т.П., его многочисленные выспренные стихотворения не способны предоставить скольконибудь вразумительного материала. Исключением в творчестве Фортуната является лишь прозаическое «Житие святой Радегунды», которое тем не менее лишь чуть менее бедно, чем его поэзия.

Bce прочие авторы (Сидоний Аполлинарий [5], Фредегар [6], Рихер Реймский [7] и их современники, список которых весьма ограничен) вполне сопоставимы с названными выше по объему и, главное, качеству предоставляемой информации. С учетом сказанного ситуация представляется более чем плачевной. Неудивительно и вполне оправданно, что именитые исследователи, описывая материальную жизнь раннего средневековья, либо предпочитают расширять хронологические или территориальные рамки, чтобы хоть как-то увеличить объем данных (М. Монтанари [8], Ж. Ле Гофф [9] и др.), либо переносить центр тяжести на X-XIII столетия, несравнимо более богатые материалом (Ж. Дюби [10], Э. Поньон [11] и др.).

Несомненно, это не вина, а беда современных историков. Скудость имеющихся сведений (повторюсь еще раз) не дает возможности создать цельную картину повседневной жизни франков в VI веке. Однако же, по нашему мнению, этот прискорбный факт не отрицает попытки собрать воедино крохи знаний об интереснейшей эпохе, наполненной разделами королевства, междоусобицами, событиями знаменитой «Войны королев», в конце концов. На фоне перечисленных сочинений пирамидой Хеопса возвышается «История франков» Григория Турского, которая вполне может послужить фундаментом этой попытки.
Всяческие заболевания являются постоянным фоном жизни: Григорий сообщает об нередких вспышках чумы [12, кн. II, гл. 18, кн. VI, гл. 14, кн. VI, гл. 33, кн. Х, гл. 23 и др.], многие из которых носят разрушительный характер. Так, в 571 г. область юговосточной Франции с городами Лионом, Буржем и Дижоном подверглась тяжелейшей эпидемии, такой, что, по сообщению хрониста, невозможно было сосчитать количество погибших. Когда закончились гробы и доски для их изготовления, людей начали хоронить в общих могилах «по десять и более человек»; в базилике св. Петра только за одно воскресенье похоронили триста покойников. Григорий так описывает эту болезнь: «Сама смерть была внезапной. А именно: когда появлялась рана наподобие змеи в паху или под мышкой, человек так отравлялся ядом, что спускал дух на второй или третий день. Сила яда лишала человека сознания» [12, кн. IV, гл. 31]. Чума, как обычно, несла катастрофические последствия: так, в Альби она унесла жизни большей части горожан [12, кн. VII, гл. 1]. Чума нередко приносится заезжими кораблями: «В порт Марселя пришел из Испании корабль с обычным товаром, который невзначай и завез эту заразную болезнь. Поскольку горожане покупали различные товары с корабля, то тотчас один дом, в котором жило восемь человек, опустел, ибо домочадцы его умерли от этой заразной болезни. Этот пожар чумы... сжег весь город огнем болезни... это бедствие прекратилось только через два месяца... И впоследствии еще много раз город подвергался этой пагубе» [12, кн. IX, гл. 22]. Григорий Турский называет эту чуму «паховой», т.е. болезнью паховых желёз, иначе бубонной.

Весьма нередки случаи лихорадки [12, кн. II, гл. 23, кн. VII, гл. 1 и др.], под которой авторы, по всей видимости, имеют в виду самые многообразные заболевания. Войско короля Теодеберта во время похода в Италию подверглось «различным видам» лихорадки, отчего «многие из воинов нашли... свою смерть» [12, кн. III, гл. 32]. Жители Клермона от той же болезни умирают «в большом количестве», и среди них - небезызвестный Храмн, который так тяжко заболел лихорадкой, что у него выпали все волосы $[12$, кн. IV, гл. 16]. От лихорадки умер и король Хлотарь, причем болезнь сопровождалась у него тяжелыми приступами $[12$, кн. IV, гл. 21]. Лихорадка приводит к тяжелым последствиям: некий житель Анжера заболел настолько сильно, что лишился слуха и речи, хотя и остался жив [12, кн. VI, гл. 6].

Марин Аваншский в своей «Хронике» упоминает также об эпидемии оспы, которая охватила Галлию и Италию в 570 г., и о другой болезни, которую он называет pustula - «гнойный нарыв», свирепствовавшей там же годом позже и опустошившей страны [12, прим. 31 к кн. IV, гл. 31]. O том же, похоже, рассказывает и Григорий Турский: «Оспа с волдырями и нарывами и другие болезни, унесшие в могилу много народа» [12, кн. VI, гл. 14].

Настоящим бичом была дизентерия, нередко обращавшаяся в эпидемию [12, кн. IX, гл. 13 и др.]. Следует отметить, что это чаще всего упоминаемый авторами недуг. «Когда короли враждовали и вновь готовились к братоубийственной войне, дизентерия охватила почти всю Галлию. У тех же, кто ею страдал, была сильная лихорадка с рвотой и нестерпимая 
боль в почках; темя и затылок были у них тяжелыми. То, что выплевывалось изо рта, было цвета желтого или, вернее, даже зеленого. Многие утверждали, что там находится яд. Простые люди называли эту болезнь внутренней оспой» [12, кн. V, гл. 34]. O том же сообщает «Книга истории франков» [2, кн. III, гл. 32].

При этом от болезни оказываются не застрахованы и власть предержащие: «Книга истории франков», например, сообщает о смерти сына Брунгильды в г. Меце [2, кн. IV, гл. 39]. Григорий пишет о том, что от дизентерии скончался сын Хильперика Самсон. Заболела и его мать, Фредегонда, но поправилась [12, кн. V, гл. 22]. Дизентерия унесла и другого сына короля, Теодорика [12, кн. VI, гл. 34]. Фредегар пишет о трех сыновьях Хильперика, умерших от этой болезни [6, кн. III, гл. 84]. От дизентерии умер и король Дагоберт [6, кн. IV, гл. 79], причем «Книга истории франков» называет его болезнь лихорадкой [2, кн. IV, гл. 42].

Также источники упоминают желтуху: «А тем временем, когда Рокколен вел себя так, его покарал бог. Но он, сделавшись желтым от царской болезни...» $[12$, кн. V, гл. 4, кн. VI, гл. 10; 2, кн. III, гл. 32 и прочие случаи]; эпилепсию: «Сильвестр стал собираться в путь. В это самое время его сразила падучая болезнь, которой он давно уже страдал» $[12$, кн. V, гл. 5]; глазные болезни: «Левнаст, архидиакон буржский, из-за бельма лишился зрения. Хотя он ходил по многим врачам, он никак не мог восстановить зрение» [12, кн. V, гл. 5], наконец, подагру [12, кн. V, гл. 42].

Страждущие обращаются за лечением болезней не к врачам, а к священникам и святым: так, один больной (род болезни не уточняется) искал блаженного Мартина, чтобы тот исцелил его, а найдя, получил желаемое [12, кн. II, гл. 1].

Аналогичным образом упомянутый выше архидиакон Левнаст, потеряв зрение из-за бельма, два или три месяца молился в базилике св. Мартина, после чего зрение к нему частично возвратилось. Однако Григорий Турский, рассказывая эту историю, заканчивает ее весьма нравоучительно: возрадовавшись, архидиакон вернулся домой и для закрепления полученного эффекта обратился к одному иудею с тем, чтобы тот поставил пиявки на лопатки. После этого он вернулся к храму, но, сколько ни молился, зрение его так полностью и не восстановилось [12, кн. V, гл. 5]. Мнение самого епископа Турского однозначно и звучит как вердикт: излечение, пишет хронист, «ему не было даровано из-за его грехов... он оставался бы здоровым, если бы, помимо божественной силы, не воспользовался помощью иудея». Посему, заключает Григорий, «пример этот да научит каждого христианина, чтобы он, если сподобился небесного исцеления, не прибегал бы к земному врачеванию» [12, кн. V, гл. 6].

Святые исцеляют слепоту молитвой и начертанием священным елеем креста [12, кн. VI, гл. 6]; тем же способом изгоняются злые духи. Этим прославились затворник Госпиций и епископ Домнол, который, кроме прочего, ставил на ноги калек [12, кн. VI, гл. 10].

Лучшим способом лечения чумы остается профилактика, т.е. бегство. Так, после разрушительной эпидемии в Нарбонне и Альби, свирепствовавшей на протяжении трех лет, жители понемногу начинают возвращаться в свои дома, но чума вспыхивает вновь
[12, кн. VI, гл. 33, кн. IX, гл. 22 и др.]. Случаев врачевания чумы источники не описывают.

Способы лечения дизентерии, упоминаемые в «Истории франков», вызывают сомнения: многие, как пишет Григорий, ставили банки на лопатки или на бедра, появлялись нарывы, которые лопались, гной вытекал, вследствие чего, однако, наступало выздоровление [12, кн. V, гл. 34]. Без сомнения, это счастливая случайность, поскольку представления о причинах появления и распространения этой болезни зачастую были далеки от медицинских. «Книга истории франков» сообщает, что «королева Австригильда, обрученная с королем Гунтрамном, страдая от этой напасти, пожаловалась мужу на врачей, утверждая, что болезнь так усилилась из-за их небрежения по отношению к ней. По приказу Гунтрамна врачи были умерщвлены различными видами казни, сама же она, слабея после этого, скончалась» [2, кн. III, гл. 32]. О том же пишет Фредегар [6, кн. III, гл. 82].

Банки же, судя по всему, вообще являются универсальным способом лечения всего, чего только можно. Так, некий Эберульф, постельничий короля Гунтрамна, так сильно избил одного пресвитера, что тому грозила смерть. И тот умер бы, пишет Григорий, «если бы ему не помогли банки, которые поставили ему врачи» [12, кн. VII, гл. 22].

Не менее интересен рецепт излечения от лихорадки, которая лишила речи и слуха безымянного жителя Анжера: некий затворник Госпиций, прославившийся своими чудесами, схватив больного рукой за волосы, «притянул голову больного к окну, затем взял освященный благословением елей и, держа левой рукой его за язык, возлил ему масло на уста и на темя со словами: «Во имя господа моего Иисуса Христа, да отверзнутся уши твои, да отомкнет уста твои сила сия, которая некогда изгнала нечистого духа из человека глухого и немого». Способ, правда, вызывает сомнения, ибо, хотя анжерец и остался жив, слух и речь к нему так и не вернулись [12, кн. VI, гл. 6]. Ничуть не более убедителен способ, к котором прибегнул некий епископ. После того, как лихорадка пошла у него на убыль, на его ногах появилась сильная сыпь. Тогда епископ велел наложить себе на голени компресс из шпанских мух, который оказался слишком сильным. Как результат, ноги начали гноиться, и упомянутый священнослужитель «закончил жизнь на тридцать третьем году своего епископства и на семидесятом году своей жизни» [12, кн. VI, гл. 15].

Григорий Турский упоминает также о своеобразном способе лечения желтухи: некий Рокколен, заболев «царской болезнью», по сообщению епископа, «то и дело ел крольчатину» [12, кн. V, гл. 4].

«Книга истории франков» рассказывает о Маврилионе, епископе Кадурки, который пытался вылечить подагру, прикладывая к голеням и стопам горячее железо, из-за чего впал в еще большую болезнь [2, кн. III, гл. 33]. Впрочем, у Григория Турского мы видим иное видение этой истории: Маврилион делал это не для лечения, а для того, чтобы ещё больше увеличить свои страдания [12, кн. V, гл. 42].

Наконец, Григорий сообщает о некоем Парфении, который был настолько большим любителем поесть, что для того, чтобы побыстрее вернуться к пиршественному столу, для «быстрого пищеварения принятой им снеди употреблял алоэ» [12, кн. III, гл. 36]. 
Теперь о том, что касается сведений о гигиене.

Белье стирали, по крайней мере - епископское, при этом среди господских слуг, по всей видимости, должности прачки не предусмотрено: Григорий Турский сообщает, что одежду некоего епископа Брикция его слуги регулярно относили для стирки одной женщине [12, кн. II, гл. 1].

Бани и вообще горячие ванны - отнюдь не редкость, и такой способ гигиены упоминается довольно часто и является привычным. Так, первое, что приказывает некий Андархий после переезда на новое место жительства, это «приготовить ему обед и согреть воды для купания» [12, кн. IV, гл. 46]. Король Дагоберт принимает ванну каждодневно: «В тот же день, в который он поехал судить из Латона в Шалон, прежде чем забрезжил свет, во время приема купания он дал приказ убить Бродульфа, дядю своего брата Хариберта» [6, кн. IV, гл. 58]. Некие епископы каждодневно много времени проводят в бане, совмещая мытье с принятием пищи [12, кн. V, гл. 20]. Бани имеются при монастырях, причем находятся в общем пользовании: там моются не только монахи, но и слуги, однако же людям, не входящим в монастырский штат, вход туда запрещен. При этом надзор за установленным порядком, судя по всему, был не особо строг, так что посторонние приходили в баню мыться, что было вменено в вину одной аббатиссе $[12$, кн. X, гл. 16]. Эпизод этот ценен как иллюстрация того, что пользование банями было отнюдь не только прерогативой некоей привилегированной части населения. Кроме этого, немаловажно еще следующее соображение: Григорий Турский упоминает, что «новое здание бани сильно пахло известью, и, чтобы не повредить своему здоровью, монахини в ней не мылись», что с очевидностью показывает, что франки не только пользовались римскими банями, но и строили новые. Баня отнюдь не была чем-то экзотическим, хотя справедливости ради стоит отметить, что утверждать что-то определенное о гигиене основной массы населения мы не имеем никакой возможности по причине банального отсутствия сведений.

Следует отметить, что бани не всегда используются по прямому назначению. Так, король Теодад, разгневавшись на некую женщину, приказал жарко натопить баню и запереть ее там вместе со служанкой. Пар был настолько горяч, то женщина потеряла сознание и скончалась [12, кн. III, гл. 31].

Моются не только целиком. Поддержание чистоты, по крайней мере у знатных франков, в порядке вещей: так, король Хильперик приказывает «подать воды... для омовения рук» [12, кн. VI, гл. 5]. Королева Радегунда, много времени уделявшая уходу за бедными и больными, после завершения процедур также моет руки, и в том числе - после трапезы [13, гл. 17].

Сидоний Аполлинарий в письме своему другу Эрифию после любопытнейшего рассказа об игре в мяч, добавляет: «Итак, мы снова уселись, чтобы умыть лицо; ему (товарищу Сидония по игре - И.К.) подали воду и косматое полотенце, которое, будучи очищено от вчерашней нечистоты, висело тут случайно на веревке, натянутой блоком, перед двустворчатой дверью маленького домика сторожа. Он сказал мне, на просторе вытирая щеки...» [14]. Хотя стоит, конечно, отметить, что это рассказ о быте высшего клира, и клира галло-римского, еще не эпохи Меровингов.
Мытье головы вообще является частью ритуала по уходу за нищими и больными. Так, Венанций Фортунат нередко упоминает о том, как Радегунда моет головы детям [13, гл. 1], нуждающимся женщинам [13, гл. 4], беднякам, для которых в некоторых случаях готовят ванну [13, гл. 17], причем вода для купания предварительно нагревается [13, гл. 24], а во время благотворительной трапезы снабжает их салфетками [13, гл. 17]. Об использовании мыла или подобных средств источники не упоминают.

Данные о рационе и, тем паче, о кулинарии франков рассматриваемого периода весьма скудны. В лучшем случае это редкие упоминания неких продуктов; гораздо чаще, как уже упоминалось, хронисты обходятся общими понятиями «трапеза», «богатый ужин» и т.п.

Наиболее богатый список потенциальных продуктов, что неудивительно, предлагает «Салическая правда». Из скота здесь перечисляются свиньи [15, II], коровы [15, III], овцы [15, IV], козы $[15, \mathrm{~V}]$; из птицы - куры, гуси, журавли, лебеди и голуби [15, VII]. Франки охотятся как с помощью ловчих птиц $[15, \mathrm{VII}]$, так и собак $[15, \mathrm{VI}]$, т.е. в меню непременно присутствует мясо диких животных. Судебник упоминает даже домашних оленей [15, XXXIII]. Франки занимаются земледелием (в числе культур - ячмень, пшеница, репа, бобы, горох и чечевица) [15, XXVII], рыболовством (ловят также угрей) [15, XXVII], пчеловодством [15, VIII], а также садоводством, выращивая яблони, груши и виноград [15, XXVII]. Ягоды, если и упоминаются, то всегда дикорастущие.

Однако же этот довольно внушительный и аппетитный список никак не изменяет факта частых и опустошительных голодовок, о которых рассказывают все авторы. Наиболее частая причина голода, по мнению современников, - природные катаклизмы. Так, Григорий Турский сообщает о том, что в 507 г. зима была настолько холоднее обычной, что реки сковало льдом. Также, по его словам, люди голыми руками ловили ослабевших от холодов птиц [12, кн. II, гл. 37]. В 584 году после нашествия саранчи «мороз сильно повредил виноградники; последовавшая затем буря погубила во многих местах виноградники и посевы; то, что осталось после града, выжгла страшная засуха» [12, кн. VI, гл. 44]. Еще больший голод обрушился на Галлию в 585 году, а описание его событий в «Истории франков» весьма напоминает знаменитую хронику Радульфа Глабера: люди пекли хлеб из косточек винограда, цветков лесных орехов, корней папоротника; многие рвали зеленые всходы и делали то же самое, и проч., и проч. [12, кн. VII, гл. 45].

В качестве комментария к приведенным отрывкам из Григория Турского стоит добавить следующее. «Средневековый запад - бедно оснащенный мир, - пишет Жак Ле Гофф, - мир технически отсталый» [9, с. 238], и с этим трудно не согласиться. При тогдашнем уровне агрикультуры, примитивной технике обработки земли, следствием которой являлась, как минимум, весьма неглубокая вспашка, катастрофические последствия для потенциального урожая несли не только глобальные природные бедствия, вроде ураганов или сильных морозов, но вполне обыденные явления - сильные дожди и непродолжительные заморозки.

Однако, несмотря на то что похолодание VI века считается доказанным фактом [16, с. 168 и др.], мы с 
легкостью обнаруживаем свидетельства таких же, если не хуже, продовольственных апокалипсисов в другие эпохи, не отмеченные понижениями температуры. Иначе говоря, «ужасные холода» Григория Турского хотя и остаются объективно «ужасными», но не они являются первопричиной перманентных голодовок.

Как пишет М. Монтанари, европеец V-VI вв. «вовсе не был заядлым пожирателем диких трав и кореньев, или, при случае, свирепым каннибалом, но - гораздо чаще - нормальным потребителем пищи (он даже ел за столом, иногда и покрытым скатертью). А поскольку он боялся, что со дня на день ресурсы данной конкретной пищи могут исчерпаться, то как мог разнообразил источники съестного. Разнообразие - вот ключевое слово, позволяющее понять механизмы добывания и производства продуктов питания в те века». «Сосуществовать с голодом, терпеть его, день за днем всеми силами бороться с ним»это нормальная обыденность того времени [8, с. 12].

А поскольку любой урожай давался потом и кровью, еда становилась объектом вожделения и, как следствие, грабежей. Обилие перечисленных в «Салической правде» продуктов, очевидно, не означает равно распределенного достатка и благосостояния всех без исключения жителей королевства. А.И. Сидоров совершенно справедливо отмечает, что отнюдь не случайно только кражам свиней в судебнике посвящено целых 16 параграфов, не считая прибавлений, - больше, чем кражам овец, коз, крупного рогатого скота и т.д. вместе взятых $[17$, с. 61]. При тогдашнем уровне развития земледелия свиньи вообще имеют первостепенное значение для выживания. Некий аббат Адалард пишет, что для благополучного существования монашеской общине требуется ежегодно не менее шестисот животных [17, с. 61], притом что Адалард написал свои «Наставления» много позже рассматриваемого периода - в начале 820-х гг.

Григорий, в частности, как о довольно обыденной вещи сообщает об ограблении заморских кораблей, прибывших в Марсель, в ходе которого нападавшие захватили «семьдесят сосудов, которые обычно в просторечии называют бочками, с маслом и топленым салом» [12, кн. IV, гл. 43], и тому подобных случаях. После смерти короля некий Нектарий, воспользовавшись возможностью, «многое унес из сокровищ покойного» и, кроме прочего, «похитил из кладовых много... вина» [12, кн. VII, гл. 15]. В другом случае горожане разграбили дом некоего Эберульфа, попавшего в опалу королевского постельничего, и в первую очередь упоминается, что они вынесли оттуда много «хлеба, вина, сала и многих других вещей» [12, кн. VII, гл. 22].

Сало в рационе франков занимает особое - почетное - место. Некий Анфимий, врач, грек по происхождению, придворный короля остготов Теодориха Великого, побывавший с посольством во Франкии, пишет: «Теперь я подробно расскажу о соленом свином сале... оно считается у франков лакомым блюдом... Что до сырой солонины, которую, как я знаю, постоянно едят повелители франков, то удивляюсь, кто же им указал на это снадобье. Ибо тому, кто ест соленое сало сырым, никакого иного лекарства и не надо. Ибо оно приносит большую пользу для здоровья и является истинным противоядием для внутренностей - это отличное средство, ибо если в кишках обнаруживается какой недуг, сало его изле- чивает, а если появляются глисты и черви, то изгоняет их. Оно успокаивает желудок, а что еще лучше, благодаря этой пище и другая становится полезнее... Сырое сало обладает такими ценными свойствами, которые медики используют в снадобьях, питье и пластырях, чтобы залечивать раны, так что, употребляя сырое сало, франки становятся здоровыми» $[18$, c. 110-111].

Во время передвижения войск или мятежей обычным делом считается, когда захватчики не только присваивают скот, но и собирают урожай, молотят хлеб [12, кн. IV, гл. 42], собирают виноград с виноградников [12, кн. V, гл. 31] и только после того, как саранчой обчистят округу, направляются дальше.

При этом нельзя сказать, что урожайность была настолько низкой, что хлеба катастрофически не хватало, как о том часто говорят многие исследователи. Пример монастырей, разумеется, не является безусловным показателем, но Григорий Турский, в частности, пишет: «монахи вытащили из амбара на солнце для просушки около трех годовых запасов зерна и приказали ему [сторожу - И.К.] сторожить его [12, кн. IV, гл. 34].

Цыплята, похоже, считаются едой богатых или, по крайней мере, высоко ими ценятся. Григорий рассказывает историю некоего повара, которых так похваляется перед своим епископом: «Истинно я тебе говорю, даже если короля ты пожелаешь угостить обедом, то и королевскую еду я тебе смогу приготовить, и никто не сделает это лучше меня». Хозяин ему ответил: «...Состряпай же мне, прошу тебя, такой обед, чтобы они поразились и сказали бы: «Даже во дворце у короля лучшего мы не видывали!». А слуга говорит: «Пусть только мой господин прикажет доставить мне побольше цыплят, и я сделаю так, как ты велишь». Когда было приготовлено все, что просил слуга, настало воскресенье, и он состряпал великолепный обед из изысканных блюд» [12, кн. III, гл. 15]. О том же рассказывает «Книга истории франков», добавляя, что обед был приготовлен из «множества цыплят» и настолько понравился знатным гостям, что обрадованный хозяин назначил повара заведующим своей кладовой [2, кн. II, гл. 11].

В рационе присутствуют ягоды. В «Истории франков» рассказывается о двух путниках, которые долго путешествовали на голодный желудок, но наконец насытились плодами сливы и ежевики, которые росли вдоль дороги [12, кн. III, гл. 15]. Также упоминаются оливковые и виноградные сады $[12$, кн. IV, гл. 42]. В пищу употребляют каштаны, которые даже могут быть предметом подношения королеве. «И подношение полей я сельским вам шлю подареньем, нежны каштаны, сей плод древа с земли моея», - пишет Венанций в письме св. Радегунде [19, с. 174]

Рационы затворников и отшельников много беднее. Так, некий Патрокл из Буржа не пил ни вина, ни других крепких напитков, но лишь подслащенную медом воду; мясо он не употреблял, отдавая предпочтение хлебу, размоченному в воде и посыпанному солью [12, кн. V, гл. 10].

Немногим более богато меню воздержанного епископа, в которое входят суп из гороха и птицы, хлеб и немного вина [12, кн. V, гл. 18], причем хлеб употребляется ячменный, а не пшеничный $[12$, кн. X гл. 8]. Бобы, в принципе, считаются едой для бедных и невзыскательных: когда авторы хотят подчеркнуть благочестие того или иного персонажа, обязательно 
следует упоминание о том, что в пищу он/она не употребляет ничего, кроме бобов, к примеру чечевицы $[13$, гл. 4]. Тот же Фортунат упоминает о том, что чечевица - это корм и лакомство для коней [20, с. 142].

Крайне воздержанная св. Радегунда за столом «тайно ела ржаной и ячменный хлеб, который прятала под пирог, чтобы никто не заметил... даже в болезни она не ела ничего, кроме бобов и зеленых овощей: ни фруктов, ни рыбы, ни яиц; и она ничего не пила, кроме мульсума (mulsa) или сидра из груш, не прикасаясь ни к неразбавленному вину, ни к медовухе или пиву» $[13$, гл. 15 , гл. 21], а во время Великого поста ограничивала себя «корнями травы или зеленью мальвы без капли масла или соли» $[13$, гл. 22]. К слову сказать, мульсум - это то же вино, только с медом. При этом бедняков в дни бесплатной раздачи еды Радегунда кормит хлебом и мясом, а первому встреченному в этот день нищему предлагает молодое неразбавленное вино [13, гл. 17].

Здесь стоит отметить, что, по всей видимости, традиции виноделия в Галлии не прерывались никогда. Св. Проспер в V веке почти с отчаянием писал: «Если бы целый океан обрушился на Галлию, его отхлынувшие воды не оставили бы большей разрухи; скот весь пропал и все плоды земные. Ни следа не осталось от лозы и олив...» $[21$, с. 96$]$. Однако при этом Фортунат, епископ Пуатье, столетие спустя пишет, с какой радостью он нашел Мозель в том же виде, в каком его описал Авсоний за два века до этого - по крайней мере, в части виноградников [21, c. 96]. Х. Джонсон пишет о том, что множество епископов ранней франкской церкви целенаправленно занимались виноделием, начиная с св. Мартина: св. Григорий, св. Жермен, аббатство которого занимало земли на левом берегу Сены, Григорий Лангрский в восточной Франции, св. Эрмелунд в устье Луары и т.д. Вскоре частную инициативу епископов перехватили крупные монастыри [21, с. 97].

В любом случае, вино у франков - известный, популярный, хотя и недешевый напиток. Им скрепляют мирный договор: в частности, после переговоров короли Хлодвиг и Аларих «пообедали, выпили вина и расстались с миром, пообещав друг другу дружбу» [12, кн. II, гл. 35].

Ужинают нередко до ночи и потом ложатся спать: «В полночь, когда все встали из-за стола и легли спать, Леон последовал за зятем хозяина в его комнату, прихватив вино и предлагая ему выпить» [12, кн. III, гл. 15]. В другом месте, рассказывая о двух епископах, Григорий так описывает их времяпрепровождение: они пьют вино всю ночь и утро, спят, затем, пробудившись, отправляются в баню, где продолжают пить и есть, причем «возлегая» за пиршественным столом до самого вечера $[12$, кн. V, гл. 20]. В целом франки, в том числе и высокопоставленные, довольно невоздержанны в питье: однажды ночью, по словам епископа Григория, некий Хульдерик выпил так много вина, что задохнулся, «и его нашли мертвым в своей постели» [12, кн. Х, гл. 22]; а 17-й епископ Тура, Гунтар, настолько пристрастился к вину, что «стал почти невменяемым» $[12$, кн. Х, гл. 31] и т.п.

Вино употребляется как местное, так и привозное, из сирийских городов Лаодикеи и Газы, которое считается более крепким. Пьют его, смешивая с не- кими «ароматами» [12, кн. VII, гл. 29]. Вина из Лаодикеи также именуются «латинскими» или «белыми».

Вино иногда потребляется не в чистом виде, но как составная часть блюд. При этом вино входит в рацион даже бедных слоев населения: «...юноша сказал пресвитеру: «Да простит нас господь в этот святой день, но дай нам, умоляем, чего-нибудь поесть, ведь четыре дня мы не брали в рот ни мучного, ни мясного». Тот, спрятав у себя молодых людей, дал им кушанье, приправленное вином и хлебом». В подлиннике значится «infusum», от глагола «infundere», т.е. «вливать». Вероятно, в данном случае речь идет о похлебке, приправленной вином и хлебом [12, кн. III, гл. 15].

Вину также приписываются целебные свойства. Венанций Фортунат в одном из своих стихотворений пытается убедить св. Радегунду пить вино, ибо «Павел... пить повелел вино, чтоб желудок сберечь» [22, c. 169].

В числе алкогольных напитков весьма распространенным у франков является абсент (absentium), т.е. полынная водка, которую иногда даже смешивают с вином и медом. Именно при помощи этого напитка, подмешав в него яд, королева Фредегонда избавилась от неугодного ей епископа Ромахара [12, кн. VIII, гл. 31]. Также франкам известен сидр [6, кн. IV, гл. 36].

К великому сожалению, о кулинарии франков рассматриваемого периода источники не говорят ничего, но при реконструкции меню знатного человека в какой-то степени можно руководствоваться «Посланием о вкусной и здоровой пище... Анфимия славному Теодориху, королю франков» [18], в котором нашлось место всему: от советов по употреблению ягод и орехов до сложных рецептов. Главное для Анфимия - это польза продуктов. Увы, мы не можем судить о практической востребованности его в основе средиземноморских рецептов при дворах франкских королей. Ф. Бродель более чем категорично утверждает, что до конца XV века рассуждать о кулинарии как искусстве вряд ли возможно: нигде в Европе «не было утонченной кухни». Количество преобладало над качеством, и в лучшем случае мы можем говорить лишь о «роскоши обжорства» [23, с. 206].

\section{Список литературы:}

1. Шекспир В. Трагедия о Гамлете, принце Датском / Пер. М.Л. Лозинского // Полное собрание сочинений: В 8 т. Т. 5 / под ред. А.А. Смирнова. М.-Л.: Изд-во «Academia», 1936. С. 1-175.

2. Liber historiae Francorum // Monumenta Germaniae Historica. Vol. II. Hannoverae: Impensi Bibliopolii Hahniani, 1888. P. 215-328.

3. Венанций Фортунат. О господине короле Сигиберте // Венанций Фортунат. Избранные стихотворения. Кн. VI, I. М.: Изд-во «Водолей», 2009. С. 100-104.

4. Венанций Фортунат. К Хильперику и Фредегунде // Венанций Фортунат. Избранные стихотворения. Кн. Х, III. М.: Изд-во «Водолей», 2009. С. 151.

5. Сидоний Аполлинарий. Письма // Памятники средневековой латинской литературы IV-IX веков. М.: Наука, 1970. С. 93-101.

6. Хроники Фредегара. СПб.: Изд-во «Евразия», 2015. 464 c.

7. Рихер Реймский. История. М.: Изд-во РОССПЭН, 1997. 336 с. 
8. Монтанари М. Голод и изобилие. История питания в Европе. СПб.: Изд-во «Александрия», 2009. 288 с.

9. Ле Гофф Ж. Цивилизация средневекового Запада. М.: ИД «Прогресс-академия», 1992. 376 с.

10. Дюби Ж. Европа в средние века. Смоленск: Изд-во «Полиграмма», 1994. 320 с.

11. Поньон Э. Повседневная жизнь Европы в 1000 году. М.: Изд-во «Палимпсест», 1999. 384 с.

12. Григорий Турский. История франков. М.: Издво «Наука», 1987. 464 с.

13. Venantius Fortunatus. Vita Sanctae Radegundis // Monumenta Germaniae Historica. Vol. 1. Hannoverae: Impensi Bibliopolii Hahniani, 1888. P. 364-377.

14. Сидоний Аполлинарий. Книга V, Письмо 17. К Эрифию // Памятники средневековой латинской литературы IV-IX веков. М.: Наука, 1970, С. 96-98.

15. Салическая правда / Пер. Н.П. Грацианского; под ред. В.Ф. Семенова. М.: Изд-во: «Образцовая тип. им. Жданова», 1950. 168 с.

16. Борисенков Е.П., Пасецкий В.М. Тысячелетняя летопись необычайных явлений природы. М.: Изд-во «Мысль», 1988. 522 с.
17. Сидоров А.И. В ожидании Апокалипсиса. Франкское общество в эпоху Каролингов. VIIIХ века. М.: Изд-во «Наука», 2018. 226 с.

18. Послание о вкусной и здоровой пище достопочтенного комита и посланника Анфимия славному Теодориху, королю франков // Горелов Н.С. Закуска для короля, румяна для королевы. СПб.: ИД «Азбука-классика», 2008. С. 107-120.

19. Венанций Фортунат. Еще одно, о каштанах // Венанций Фортунат. Избранные стихотворения. Кн. XI, XIII. М.: Изд-во «Водолей», 2009. С. 174.

20. Венанций Фортунат. К нему же // Венанций Фортунат. Избранные стихотворения. Кн. VII, VIII. М.: Изд-во «Водолей», 2009. С. 142-144.

21. Джонсон Х. История вина. М.: Изд-во «BВPG», 2004. $480 \mathrm{c}$.

22. Венанций Фортунат. Еще к ней же, чтоб пила вино // Венанций Фортунат. Избранные стихотворения. М.: Изд-во «Водолей», 2009. Кн. XI, IV. С. 169.

23. Бродель Ф. Структуры повседневности. Материальная цивилизация, экономика и капитализм XVXVIII вв. Т. 1. М.: Изд-во «Прогресс», 1986. 622 с.

\section{THE DAILY LIFE OF THE FRANCS ACCORDING TO WRITTEN SOURCES AT THE TIME OF GREGORY OF TOURS: DISEASES, MEDICINE, HYGIENE AND FOOD}

(C) 2019

Kazakov Igor Valentinovich, candidate of historical sciences, associate professor of World History, Law and Methods of Teaching Department Samara State University of Social Sciences and Education (Samara, Russian Federation)

Abstract. This paper is an attempt to collect and systematize information about the material conditions of life in the Frankish state of the Merovingians in the $6^{\text {th }}$ century. The choice of the topic is due to the need to compose a complete picture of a person's life from the beginning of the early Middle Ages, which until now has remained poorly researched, unlike the Carolingian period. The sources used are the writings of Gregory of Tours, Venantius Fortunatus, Apollinaris Sidonius, The Chronicle of Fredegar, «The History Book of the Franks» and others. The paper contains data on the diseases and epidemics that were widespread during the mentioned period, methods of their treatment and the state of medicine in general, hygiene in the Frankish society, as well as the diet and composition of products. The collected material says that: a) the sources of the early Merovingian period are extremely scarce data in the field of life descriptions; b) the Frankish society was very vulnerable to a wide variety of diseases, and the priority of faith over medicine did not allow them to resist; c) ideas about the absence of elementary hygiene in the early Middle Ages are greatly exaggerated, and d) the set of consumed products was distinguished by simplicity and at the same time diversity with rudimentary skills in cooking.

Keywords: Merovingians; Gregory of Tours; Fredegar; Venantius Fortunatus; The History Book of Franks; daily life; Frankish state; early Middle Ages; diseases; epidemics; medieval medicine; medieval hygiene; food in middle ages; The Salic law; material conditions; $6^{\text {th }}$ century.

УДК 94 (367) : $929.5 \ll 15 »$

DOI 10.24411/2309-4370-2019-11203

Статья поступила в редакцию 09.12.2018

\section{К ВОПРОСУ О ПРОИСХОЖДЕНИИ КНЯЗЯ МИХАИЛА АНДРЕЕВИЧА ЛЕТОПИСНОЙ СТАТЬИ 1305 ГОДА}

(C) 2019

Абуков Сергей Навильевич, кандидат исторических наук,

доцент кафедры историографии, источниковедения, археологии и методики преподавания истории Донецкий национальный университет (2. Донеик, Донецккая Народная Республика)

\footnotetext{
Аннотация. Среди многих спорных вопросов отечественной генеалогии особое место принадлежит проблеме происхождения князя Михаила Андреевича летописной статьи 1305 г., о котором известно, что он женился в Орде и приехал в Нижний Новгород, где казнил восставших жителей. Проблема его происхождения связана с ранней историей династии суздальско-нижегородских князей и наследованием власти на Руси в эти годы. Вообще, история русских земель в XIII-XIV вв. слабо освещена источниками, и каждый новый факт дополняет наше представление об этом периоде. Имя отца князя не упоминается в источниках. В научной литературе существуют два противоположных мнения, которые невозможно объединить. Одни историки считают этого князя сыном Андрея Александровича Городецкого и внуком Александра Невского, другие -
} 